\title{
The Clash of Traditional and Modern Cultures in the Novels Samdae (Three Generations) by Yeom Sang Seop and Tetralogi Buru (Buru Quartet) by Pramoedya Ananta Toer
}

\author{
Febriani Elfida Trihtarani \\ Department of Language and Literature, Universitas Gadjah Mada, Indonesia \\ Email: febrianielfida08@ugm.ac.id
}

\begin{abstract}
This study analyzes Korean writer Yeom Sang-seop's colonial-era novel Samdae (Three Generations) (1931) and Pramoedya Ananta Toer's Tetralogi Buru (Buru Quartet). Although Korea and Indonesia have different cultures, they share a history of colonization by imperial countries. The purpose of this study is to analyze the writers' cultural differences as they appear in these novels. Yeom Sang-seop's Samdae (Three Generations) is shown to capture the conflict of traditional and modern cultures. In this novel, characters who follow traditional culture consider customs and honor very important. Meanwhile, the characters in Pramoedya's quartet consider honor to be important. In Yeom Sang-seop's novel, those seeking modernity hold only modern ideas and ultimately fall victim to consumerism. On the other hand, in Pramoedya's novels, while characters with modern ideas do exist, they are not trapped in a world of consumerism. Yeom Sang-seop seeks a solution to escape colonialism through one character who is not interested in traditional culture but also shows no significant interest in modern culture. He instead supports socialism, which can be considered an attempt to avoid the downsides of modernity. In the novels of Pramoedya, one character Minke faces a similar situation. Through his national organizing activities, he shows the possibility that Indonesia can break free of colonialism.
\end{abstract}

Keywords: Yeom Sang-seop; Pramoedya Ananta Toer; cultural difference; cultural conflict; modernity; traditional

\section{INTRODUCTION}

The process through which communities are built in new lands involves the erasure or reshaping of existing communities. This process, broadly speaking, may emerge as a result of trade, occupation, negotiation, war, genocide, slavery, or rebellion. Meanwhile, colonialism may be defined as a form of occupation or conquest, including the control of land and goods belonging to others (Loomba 1998).

Korea and Indonesia are both countries with colonial pasts. Both experienced a time of Japanese occupation, and both obtained their independence in a similar time span. The Japanese occupation of Korea lasted 35 years (1910-1945), beginning with the fall of
Korea's Joseon Dynasty. Japanese occupation of Korea is described as a dark time in the country's history, where the Japanese controlled almost all aspects of life and the Korean people suffered (Seth 2011). Meanwhile, Indonesia was occupied by Japan for three and a half years, between 1942 and 1945, following more than 350 years of Dutch colonialism.

Based on the historical similarities between these two countries, despite having different cultures, it is interesting to compare and contrast colonial literary works from these countries. The important role of literature in colonial and anti-colonial discourse has been widely explored. Literature has served as a mediator of the real 
and the imagined. Literary texts, collections of linguistic units and complex signs, can be viewed as fertile sites for ideological interactions. Works of literature written during and after such colonial occupations have commonly applied, adapted, and embedded 'other' cultures into them, creating new genres, ideas, and identities (Loomba 1998).

By examining works of Korean and Indonesian literature, it is thus possible to understand the different colonial viewpoints and conflicts reflected within them. This research will examine the works of two internationally recognized writers, one Korean and one Indonesian. The Korean writer most worthy of being called an international author is Yeom Sang-seop (Kim 2013). Yeom Sang-seop could be considered to have filled a gap in depicting Korea's experiences in the colonial era through his works of literature. His main works, are Samdae (삼대, Three Generations), Mansejeon (만세전, Before Liberation), Haebang-eui Adeul (해방의 아들, Children of Liberation), and Hyopung (효풍) (Kim 2009).

In writing his literature, he depicts characters with complicated lives, such that, compared to other writers, his are more realistic in their depiction. There are many views of literature. Elements that can be noted in his works include realism, naturalism, nationalism, anti- feudalism, antiimperialism, etc. Most prominent, essential to all of Yeom Sang-seop's literary works, are realism, nationalism, imperialism, and anti-feudalism (Munhakgwa Sasang Yeonguhoe 2008).

Yeom Sang-seop's works took up issues of colonialism and reflected complex social problems through their diverse and numerous characters, issues which had been neglected by other writers. This research will focus on one of Yeom Sang-seop's early novels, which takes the colonial era as its background, and compares this with Indonesian works set in the colonial period.

The most internationally recognized Indonesian author, though not widely known in Korea, is Pramoedya Ananta Toer (1925-2006) (Vltchek and Indira 2011). Pramoedya was a writer who frequently used a colonial setting for his works. He was born during the Dutch colonial era, and the contemporary situation was frequently used as the setting for his works. His early published work includes Keranji Bekasi Jatuh (The Fall of Kranji-Bekasi, 1947), Perburuan (The Hunt, 1950) and Keluarga Gerilya (Guerilla Family, 1950).

However, because he was involved in the Lembaga Kebudajaan Rakjat (Lekra - Institute for People's Culture), he was considered a leftist and thus imprisoned for four years, from 1965 to 1969. In 1969, he was exiled to Buru Island, where he was held with other prisoners until 1979. While in exile, Pramoedya wrote his most famous works: the Tetralogi Buru (Buru Quartet), consisting of Bumi Manusia (This Earth of Mankind, 1980), Anak Semua Bangsa (Child of All Nations, 1980), Jejak Langkah (Footprints, 1985) and Rumah Kaca (House of Glass, 1988) (Koh 1993).

Although Yeom Sang-seop and Pramoedya were active in different countries in different eras, they both actively wrote during the colonial era. Unlike other writers, they realistically depicted the conditions experienced during the colonial era and after independence. A comparative study of the works by these authors will provide an in-depth understanding of their sharp criticism and perspectives about the colonial experience. Even when they were active after independence, they used the colonial era as the background for their works and similar themes. Many elements of these novels reflect the conflict between colonizers and the colonized, as well as conflict between tradition and modernity through interactions with different cultures. It is these similarities that will be examined in this article. The novels discussed are those set in the colonial era, which include a number of post-colonial themes. These works are Yeom Sang-seop's Samdae (삼대, Three Generations, 1931) and Pramoedya Ananta Toer's Tetralogi Buru (Buru Quartet).

Samdae (Three Generations) can be seen as Yeom Sang-seop's most celebrated novel which presents as a canvas with varied characters including intellectuals, bourgeouis, working-class men and women, and also revolutionaris. This novel portrays the conflict within an upper-middle class family during the Japanese colonial period that also highlights the changing of everyday life of Korea in that period (Park, Gatrall 2010). This novel centers on three generations of the Jo family: Jo Ui-gwan, his son Jo Sang-hun, and his grandson Jo Deok-gi. One of this novel's most prominent themes is the conflict between the conservatives who uphold traditions, represented by Jo Ui-gwan, and people who have been influenced by modern thought and chase everything and anything that appears modern, represented by Jo Sang-hun. The youngest Jo, meanwhile, is located between these two opposite forces, and is key to the author's message about how contemporary issues in Korea should be resolved.

Meanwhile, the Tetralogi Buru (Buru Quartet) follows Minke, the son of a Javanese nobleman which is called priyayi and those with whom he interacts in Java. In the first novel in the series, Bumi Manusia (The Earth of Mankind), Minke meets Annelies Mellema, and the 
novel follows the love of an indigenous man and a mixedrace woman. The indigenous characters Minke and Nyai Ontosoroh (Annelies' mother) begin fighting against their unfair treatment at the hands of the colonial government. By the time of the second work, Anak Semua Bangsa (Child of Nation), Minke has developed a great sense of nationalism. He challenges colonialism and attempts to uphold the rights of indigenous people by writing in Malay, after some time writing in Dutch. In Jejak Langkah (Footsteps), Minke establishes an organization for indigenous peoples, which poses a great threat to the colonial government. The final work in the quartet, Rumah Kaca (House of Glass), takes the perspective of Pangemanann, a police officer who supports colonialism, and follows the mushrooming of anti-colonial and nationalist indigenous organizations following the exile of Minke.

Yeom Sang-Seop's Samdae (Three Generations) and Pramoedya's Tetralogi Buru (Buru Quartet) similarly depict their characters' behaviors in dealing with the mixture of modern and traditional cultures in the colonial eras of both countries. Not only the main characters of both works, Minke and Jo Deok-gi, but also other important characters in both novels reveal their attitudes about tradition and modernity. The theme of cultural difference during colonialism portrayed in the novels will also be analyzed in this article. By identifying similarities and differences between these novels, this article will examine the messages of the authors.

Some work has been done in comparing Korean and Indonesian literature, however none have compared works about the colonial experience of both countries. To date, there has only been one dissertation, written by Eva Latifah (2012) and titled Hangukgwa Indonesia Jeonhu Soseol Bigyo Yeongu: Hwang Sun-weongwa Nugroho Notosusanto-ui Jakphumeul Jungsimeuro (“A Comparative Study of Korean and Indonesian Post-War Novels: The Works of Hwang Sun-won and Nugroho Notosusanto"), which analyzes and compares the post-war novels of Hwang Soon-won and Nugroho Notosusanto. Thus, by conducting a research about Yeom Sang-seop and Pramoedya's colonial themed works, this research will provide a new point of view about literatures with colonial period background of both countries.

The concept of cultural difference is part of Homi Bhabha's well known theory of post-colonialism, presented in The Location of Culture (1994). Cultural difference is a process of enunciating culture as something recognizable, authoritative, and meeting the criteria for establishing cultural identification systems. This process is focused on questions of ambivalence in cultural power, i.e. the dominance of a particular culture where differences emerge. This process of enunciation introduces multiple elements, including cultural identification. It problematizes the binary division between past and present, tradition and modernity, within social representation and power (Bhabha 1994).

Cultural differences, one of which is created from the colonization process, are able to create two cultural forms, namely modern culture and traditional culture thus modernity or tradition. These two things are portrayed clearly in both novels of the authors analyzed in this research. This similarity is created possibly because of the colonial experiences happened in both countries experience universal experience.

Modernity itself can be seen as a process of enlightenment from a tradition that limits humans from their freedom. It can also be regarded as a process to break away from tradition (East 2006). Because traditional cultures are identical with numerous norms that limits humans' freedom. The process of modernism itself is viewed as a movement that was expanded and developed in the early 20th century which was caused by intercultural exchanges so as to develop interpretations of the cultural structure of each region that encounter (Friedman 2006).

Modernity is often accomplished with intensification of intercultural contact zones, both are generated through conquest, enormous voluntary or forced migration of people, or a peaceful commercial traffic and exchange of echoes or culture. Therefore, one of the conquest forms of intercultural contact zones can be the form of colonialism. Colonialism itself has a huge role to enable the development of modernism, particularly in the Western modernisms. It is created through the process of indigenization of cultural practices from elsewhere. The colonized localized Western modernity and modernism to create their own form of modernity under the colonial power and resistance (Gikandi 1996, as cited in Friedman 2006).

Meanwhile, the concept that is interconnected with modernity is tradition. These two concepts are interconnected because modernity tries to break the relationship with the past, to distinguish between the present and the past and also, modernity suppresses its relationship with the past (Clifford 2004, as cited in Friedman 2006). The termination of modernity with the past has caused a radical reaction with things that are contrary to that. As a result, this modern period is sometimes filled with contradictions between modern and traditional people thus can be called modernist and traditionalist. The former are those who want to promote 
modern ideas and the latter are those who want to restore and maintain traditional ideas. Sometimes the conflict between modern and traditional forces that is significant becomes the character of modernity itself (Friedman 2006).

Through the characters in the novel, both authors, Yeom Sang-seop and Pramoedya Ananta Toer, distinctly depicts the conflict between modernists and traditionalists in both countries. Therefore, this paper will examine the cultural differences that emerge within these two novels, as well as the cultural conflicts and solutions offered by the authors of the novel.

\section{DISCUSSION}

\section{Between Tradition and Honor}

Samdae (Three Generations) and Tetralogi Buru (Buru Quartet) are both characterized by different perceptions regarding national culture, represented by characters who are pro-tradition and by characters who support modernity. This chapter will first discuss the novels' protradition characters. In Samdae (Three Generations), this character type is represented by Jo Ui-gwan, the eldest of the Jo family. Generally, the elderly are viewed as holding firmly to conservative ideals. This common perception is reflected in Jo Ui-gwan, a grandfather with great respect for the values of feudalism. He holds particularly dear the jesa 제사 (ritual), which is intended to honor the ancestors.

"I know you people don't care about ancestral rites since you've become involved in Christianity and whatnot," the old man said. "But there's nothing you can do about it while I'm still alive!"

The old man began his usual sermon. "Even if you believe in Christianity, or something more important than that, there's nothing wrong with holding memorial rites for your parents. They say Jesus didn't know who his father was, but he was born thanks to his parents, wasn't he? Deok-gi, you listen carefully!" he shouted toward the veranda. He went grumbling about Christianity, then moved to the topic of his son (Yeom 2001).

As seen in the quotes above, early in the novel, Jo Ui-gwan is depicted as busy preparing the annual ritual for his deceased father. This reflects the high value that he places on tradition. His willingness to follow these rituals shows his character. Aside from the jesa (제사) such ritual or ancestral rites for his deceased father, the elder Jo also regularly holds a traditional tea-drinking ceremony for New Years, called darye 다례. Even when he falls ill at the end of the novel, he continues to think of these traditions, as seen in the following quote.

He thought it was not a good idea to have an operation on the last day of the year and advised that it be put off until two days after New Year's. When the patient heard that it was actually the last day of the year, he turned to his grandson and asked, "Is today already the last day of the year? Have you prepared for the ancestral ceremony tomorrow?

"Would you matter if our ancestors didn't receive any offerings this year, in light of your illness?" asked Deok-gi.

The old man lost his temper. If they acted this way while he was still alive, what did they intend to do after his death? Deok-gi agreed to do as his grandfather wished and left (Yeom 2001).

This quote highlights the importance of tradition for Jo Ui-gwan. His dedication to tradition also influences his actions and activities when dealing with internal conflicts, such as his disapproval of Christianity, identified with progressiveness and modernity, which put him in conflict with his son, Jo Sang-hun. At the time, Christianity was considered representative of modern culture, and thus conservative residents could not readily accept it. His disapproval of his son's and grandson's activities indicate that he remained caught in the spirit of feudalism.

Another indication of Jo Ui-gwan's conservative attitudes is his continued emphasis on honor. He believes that power is closely related to honor in traditional society. The higher one's position in society, the greater one's power. Jo Ui-gwan's greed in re-mapping his family tree indicates his emphasis on his family and honor. He gained a higher social class using his abundant wealth. He hoped that his family would be able to maintain and retain this high social position.

Taking over the genealogy office was the old man's most recent indulgence. This time, he was drawn into a major venture, and spent as much as two hundred thousand nyang, ten times the amount he'd spent on the Suwon woman, to create the genealogy center. It is difficult to belittle the venture, even if it went again the spirit of the times. Though Sang-hun didn't particularly object to the genealogy office, neither did he feel any urgency to promote the new project. However when his father put up a precious four thousand won in an effort to worm himself into this particular 
faction's genealogy book, Sang-hun thought he was definitely off his rocker.

Buying yangban (korean aristocrat) status! It was humiliating to Sang-hun (Yeom 2001).

Jo Ui-gwan's attitude resembles that of Minke's father in Pramoedya's the Tetralogi Buru (Buru Quartet). In colonial Indonesia, many upper-middle class people, represented in this novel by Minke's father, held traditions in great regard; similar support for tradition was given by the upper classes and nobility. As with Jo Ui-gwan, Minke's father in Pramoedya's novel sought a higher position and greater honor. As such, members of these groups had little desire to oppose Dutch or European colonial powers. Rather, they viewed these people as rulers to whom they owed the greatest loyalty and obeisance.

That man, Regent B., cleared his throat. Then slowly sat down in the rocking chair removing his slippers behind the chair's rockers and putting his noble feet on the velvet pillow. The chair started to wobble a bit. An object I had assessed to be rather long was knocking gently against my hatless head. How lacking in manners was the creature I had to honor... every gentle knock I had to greet with a gesture of gratitude too. The scoundrel!') (Toer 2001).

The description in the quote above is the main character Minke's inner thoughts when he had to present himself to his father, Regent B. Minke had to go back home to be an interpreter for his father's who was to give a speech on his inauguration as a regent. Many Dutch government officials would attend the ceremony, thus he summoned Minke who was fluent in Dutch to interpret his the speech. In this scene, his position as an aristocrat enables him to act lordly in front of those whose position is below his. Minke despised this behavour, making him disapprove every movement he had to do in front of his father. The position held by his father also allowed him to have a close relationship with the colonizers.

However, there are clear differences between Yeom and Pramoedya's novels. Although both focus on tradition, they have different emphases. In Samdae (Three Generations), Jo Ui-gwan places greater emphasis on rituals and traditional ceremonies, a perspective rooted in the Confucian philosophy that was widespread in contemporary Korean society.

Meanwhile, Pramoedya's novels focus primarily on the attitudes taken by the upper-middle classes in dealing with those of a lower social station. As Minke's father has a high position in the colonial government, serving as regent, he does not occupy an equal position with the servants and other members of the lower classes. At the time, it was common in Java for persons to obey those of higher social standing. It is this practice that the novel criticizes. Many Javanese honored and obeyed those of a higher social status, even when those people of high social status treated them poorly. It cannot be ignored that the lower classes were continuously subjugated as they lacked the power to oppose such subjugation. Pramoedya opposed this culture, viewing the requirement to obey persons of higher social standing to be illogical. In one interview, he speaks about Javanese culture as he sees it as Javanism, which he thinks as a "blind obedience and loyalty to superiors, and no respect for the rest of the people" (Vltchek, Indira 2006). Javanism was what made Java colonized by foreign countries for centuries because the elites of Java collaborated with the colonial authorities. The lower classes were not brave enough to oppose the elites, not to mention the colonizers. Pramoedya expresses this ideas clearly in the novel through the conflict between the Javanese elites and the lower class people.

\section{Tendencies in Modern Culture}

Where cultures mix, some people are not only interested in traditional culture, but also in the new culture such as that introduced by colonialism. In both novels, there are characters that prefer modern culture over traditional culture. In Yeom Sang-seop's case, this character type is one that values material goods and seeks worldly goods. Characters of this type include Jo Sang-hun, the father of Jo Deok-gi and son of Jo Ui-gwan.

The character Jo Sang-hun is not interested in tradition. He "had lived in America for almost two years" (Yeom 2001), and thus was exposed to more modern thoughts. His reason for this attitude is primarily his religious faith. As a Christian, he believes that he is no longer required to perform the traditional rituals. Jo Sanghun's refusal to perform these rituals is shown clearly in one part of the novel, where he does not attend the ritual to commemorate the anniversary of his mother's death.

"What are you trying to say? Would you even blink if I died this very moment? You ignore your own mother's memorial. Why did we even bother to give you an education?"

Deok-gi's grandfather pounded the ashtray with the long pipe he had been holding in his mouth. The old guests, who had been sitting with the old man, sat quietly with their heads bowed down as 
if in slumber, occasionally rubbing their hands together. They couldn't judge whether the elderly master of the household was right or wrong, but they believed his remarks made some sense.

Deok-gi's father responded, "Even if a person doesn't perform ancestral rites because he believes in a different religion, that doesn't mean that he wouldn't sit at his father's deathbed" (Yeom 2001).

Jo Ui-gwan thus described him as "a man who does not know his mother"2) (Yeom 1987). Consequently, Jo Sang-hun is forced into an ambiguous position within his family. He shows little concern for his father and son, seeking only material gains.

Jo Sang-hun is a devout Christian, but shows greed in his search for money and material goods, a tendency that can be considered to have emerged from the capitalist system. In several parts of the novel, he is depicted as gambling, drinking alcohol, and chasing younger women such as Hong Gyeong-ae and Kim Eui-kyung. He thus rejects traditional culture and shows only interest in money, a symbol of materialism and capitalism, and in women. His lifestyle, thus, goes against the teachings of his Christian faith. Yeom Sang-seop depicts Jo Sang-hun negatively, and by the end of the novel he is arrested by the police in relation to his father's death.

"Mother, has Father been drinking recently?" Deok-gi stopped sipping his rice tea and looked at his mother, who was turned away from him.

"Who cares what he's been doing? He could be out drinking or visiting gisaeng houses" (Yeom 2001).

From the quote above, Jo Sang-hun's wife even mocked him as someone who likes to go out drinking while visiting gisaeng or Korean female entertainers. This characterization of Jo Sang-hun presents him as a materialistic figure. As such, it can be assumed that Yeom Sang-seop was critical of the capitalism that began to emerge in Korea in the $19^{\text {th }}$ century. He perceived this capitalist lifestyle as leading people to materialism, rather than happiness. Yeom Sang-seop's message can also be seen in the highly negative description of Jo Sang-hun.

Meanwhile, although Pramoedya's Tetralogi Buru (Buru Quartet) does include characters that exhibit antipathy towards tradition, these characters are not depicted as Jo Sang-hun in Samdae (Three Generations). In this novel, the character most open to modernity is the main character, Minke. This character shows antipathy towards traditional Javanese culture, but does not embrace capitalism. Minke opposes Javanese culture when facing his father. As someone educated in modern European school systems, he perceived Javanese tradition as being pointless. For example, he saw bowing and walking on one's knees when in front of persons of higher social status as an excess of humility that must be eliminated. His antipathy towards traditional Javanese culture can be seen in the quotes below.

(1) "Yes, walk in a kneeling position, Ndoro Raden Mas," the agent was like driving a buffalo back to its wallowing place.

And the distance of nearly ten meters I covered swearing in more than three languages.

(2) Truly, my schoolmates would laugh at me heartily to see the farce of how humans, usually walking upright, on their own feet, now had to walk in a crouch, with the help of both hands. O God, you ancestors, you, why do you create a custom that humiliates your own descendants in this way?

(3) I placed my hands together in front of my face in homage as I had I seen the court officals do for my grandfather and my grandmother and my parents, at the end of the fasting month. And now I will not lower my hands before the Regent sits comfortably in his place. In paying homage I seemed to have lost of late all the knowledge that I had learned year by year. Gone is the beauty of the world as promised by the advancement of science (Toer 2001).

In the passage (1), Minke is shown to despise the acts he has to do in front of his father whose position is higher than his. While in the passage (2) and (3) it shows that he thinks that the homage and how he had to walk towards his father go against the modern knowledge he has received at school. Minke is educated in H.B.S. (Hogere Burger School; secondary school in the colonial period for the children of the Dutch, Europeans and Indonesian aristocrats) where he learns knowledge on an equal footing with Dutch students. Thus he feels giving homage to a person with ahigher position in traditional culture, passed down through Javanese ancestors, is the reason the people are unable to develop and become a part of the modern era.

Furthermore, Minke exhibits a disapproval of the Javanese language used by the Javanese people. As such, he is not shown speaking Javanese, even with his first wife, Annelies Mellema. Minke, who rejects Java and its culture, feels it unnecessary to become "Javanese". Ultimately, he decides to abandon his Javanese identity and fully embrace modernity. 
(1) "You're indeed not Javanese anymore. Being educated by the Dutch you have become Dutch, a kind of brown Dutchman. Probably you have even converted to Christianity" (Toer 2001).

(2) "Forgive me, Mother, please could you draw the keris for me, so I can see it."

"Shush! You're indeed no longer Javanese. Do you think it is the same as a kitchen knife?" (Toer 2001)

(3) "Listening to your words, it appears you would rather not be Javanese any more, Son."

"Is it truly that important to be Javanese, Mother?" (Toer 2012).

The passages above, are all from the scene between Minke and his mother. His mother keeps stressing to Minke that he is no longer Javanese. In the passage (1), she points out that his Dutch education keeps influencing Minke to be more Dutch than his own cultural trait which is Javanese. Minke has possibly experienced a transformation in terms of his thoughts or perspectives, ideology, and attitude to become more modern due to his education in a Dutch school. This modern thinking and knowledge leads Minke to develop an antipathy towards becoming a regent, and preserving his aristocrat position, instead he prefers to solve his nation's problem in a way that has more impact (Toer 2001). His antipathy about Javanese traditional culture is also shown in the passage (2) where he is depicted to not be able to withdraw a keris which is a Javanese traditional knife from its pocket on his wedding day with Annelies Mellema. In addition, he explains the unimportance of being a Javanese in the passage (3) which shows his despise about Javanese traditional culture.

This attitude of Minke's shows that, although Minke embraces modernity, he does not become tempted by materialism. Minke was born to a priyayi or aristocrat family and educated elsewhere, and thus lived apart from his parents. Among the nobility of Java, it was traditional for a son to take the same job as his father. Minke's father is a regent, and as such in keeping with Javanese culture Minke should become regent as well. His refusal to reply to the letters sent from home (Toer 2001) can be interpreted as him abandoning his comfortable life as a nobleman. After this, Minke's dislike for Javanese culture becomes stronger. He chooses to focus on freeing Indonesia from Dutch colonial power rather than living comfortably as regent.

Minke's attitude, as explained above, reflects the message being conveyed by Pramoedya. Focusing on humanity, Pramoedya sought to offer a solution for the Indonesian people and their ideals in the colonial period through Minke, who manifested the author's humanitarian attitudes. This can also be linked to the author's painful real-life experiences, after which he sought detailed knowledge of humanity. In his works, he often presents revolutionary heroes who help people get through their suffering (Koh 2011). Characters such as Minke offered knowledge to colonial society that could release the colonized from the shackles of oppression.

\section{Tendencies in Dealing with Modern Culture}

The characters discussed in this section are those with anti-colonial perspectives. In Samdae (Three Generations), this is Kim Byeong-hwa, a communist whom Jo Deok-gi calls "The Red". Kim Byeong-hwa was raised in a Christian family, but over time he decided that Christian doctrine was incompatible with his own views. As such, he decided to seek his own path, a choice that led to conflict with his father. At this time, he became interested in communism and socialism, both ideologies not represented by Christianity.

As he scraped by for a year in Tokyo, barely avoiding starvation, his disposition grew ever more radical and his resolve was toughened by the kind of life he now led. Never mind that he had broken ranks with his father - what was more surprising to Deok-gi was his discovery that Byeong-hwa's ideology had undergone a radical shift from his own (Yeom 2001).

Kim Byeong-hwa established an independence movement, based on communist ideology and intended to fight against Japanese colonialism. He also received money from a communist figure Pi-hyeok, with which he purchased the Japanese-owned vegetable shop Sanhaejin (산해진) and used it to fund the struggle for independence. Although Kim Byeong-hwa and those around him did not act openly, they were still closely monitored by the police. It can be seen that the communists in this novel are depicted as not having a bright future.

In Samdae (Three Generations), Yeom Sangseop presents the communist movement as an anticolonial one-the only anti-colonial movement in the novel. More specifically, Yeom Sang-seop depicts the communists' accretion of power through Kim Byeonghwa and his leadership of the anti-colonial movement. In contrast, in Pramoedya's Tetralogi Buru (Buru Quartet) communist movements are not depicted clearly rather 
these movements only convey ideas of class struggle.

The last character to be discussed here is Jo Deokgi, who occupies a position between Jo Ui-gwan and Jo Sang-hun. Currently studying in Japan, he is the son of Jo Sang-hun and the grandson of Jo Ui-gwan, which makes him the youngest of the three. Jo Deok-gi, who is also the main character of the novel, is not only depicted as speaking Japanese fluently, but also being a good person. His personality enables him to bridge the gap between his grandfather and his father.

However, despite having a modern mindset, he is little interested in money and women - unlike his father, Jo Sang-hun. Before his death, Jo Ui-gwan gave Jo Deokgi his inheritance, and Deok-gi did not show any greed. This character, it is implied, is seeking and addressing the question of modernity (Kim 1998) in a colonial context. Jo Deok-gi shows little interest in traditional culture, but at the same time he shows no antipathy. Such a view is reflective of the author's own views. Yeom Sang-seop was neither a traditionalist or conservative, nor a modernist (Kim 1998). Jo Deok-gi is depicted as a character of the modern era. The author's view can be seen from his thoughts about the modern woman whom he compares to his wife who grew up in an old-fashioned family, as presented below.

His grandfather had made a great fuss about finding a suitable girl for him from the right family and had forced him to marry. Deok-gi had liked his bride at first, but by the time he went to Japan he had begun to lose interest, and now he felt sorry for her, thinking how hard it must have been for her to put up with her step-grandmother-in-law while he was away.

His wife tolerated the situation because she had been raised by an old-fashioned family and had only gone to elementary school. A modern woman could have caused plenty of trouble. Deok-gi had hated the idea of marrying an uneducated woman, but given the circumstances he thought it was better that she hadn't received a modern education (Yeom 2001).

Meanwhile, Jo Deok-gi is described by Yeom Sang-seop as a solution to the problems of modern culture and its integration into society. Jo Deok-gi is also depicted as taking a neutral position, one which is between his grandfather and his father. This enables Jo Deok-gi to overcome shared problems using a different approach. $\mathrm{He}$ is not tempted by greed and lust, as shown in a scene where his grandfather entrusts him with the key to the family safe. Jo Deok-gi refuses his grandfather's request.

"If only you are right! But even if I get better, I'll be no better than a living corpse. Take these keys to the safe. I'm not going to listen to anyone. I called you home so urgently so that I could entrust these keys to you. Now that I've handed them over, I can close my eyes in peace. But don't open the safe as long as I'm alive. In the safe is your seal, but you mustn't use it until I'm gone. Take these keys, and if, by Heaven's will, I get better, return them to me."

"Why should I take them now? I should go back to school as soon as you get better, Grandfather. And how can I take these keys when my father is alive and well?" The propriety of according due respect to one's father not-withstanding, Deok-gi was in no position to give up his studies and install himself as the household's manager (Yeom 2001).

This quote shows that it was Jo Deok-gi who had finally become the manager of the household and not his father. Deok-gi still has respect for his father seen in his reluctance to accept his grandfather's request to him. His grandfather's decision in giving him the key to the safe, was because he saw Deok-gi as a more capable person to handle family affairs and not his own son. He was afraid his son would use his money and assets imprudently. Therefore he gave the key to his grandson. In the end his decision was right since Deok-gi, becoming the heir of the Jo family, he was able to easily overcome the problems that emerged after his grandfather's death. He wisely distributed his grandfather's belongings as per his request. Unlike his father, Jo Deok-gi showed little interest in his inheritance. By continuing to serve as a bridge between his grandfather and his father, Jo Deok-gi employs his own approach to addressing the problems of instability in the face of tradition and modernity. Through the character Jo Deok-gi, Yeom Sang-seop attempts to offer an alternative means of resolving the conflict between traditional and modern culture.

Deok-gi debated whether he should hear him out or cut him short. "Where did the money come from?" he finally demanded.

"That doesn't matter. I told everyone it came from you. If something happens and you're questioned, or if they bring us face-to-face, just tell them you lent me a thousand because I had renounced my ideology and wanted to start a business. Tell them that you took it from your grandfather's money 
before he died and gave it to me at the hospital" (Yeom 2001).

Yeom Sang-seop also tries to seek an alternative way in resolving the conflict between traditional and modern culture through communist activities involving Kim Byeong-hwa, Jo Deok-gi has shown interest in supporting his friend. Kim Byeong-hwa is depicted to have purchased a Japanese vegetable shop to camouflage his underground radical activities. He was given the money by a communist activist called Pi-hyeok. However as the police arrested him and interrogate him about the money, Jo Deok-gi implicated himself by telling the police that he was the one who give the money to Kim Byeong-hwa. It can be seen that Jo Deok-gi does not have any antipathy towards communism. Furthermore his interest about communism is also depicted in the passage below, stated by the police who investigated the case.

If Deok-gi's grandfather had in fact been poisoned and the main culprit was Jo Deok-gi, Geumcheon was certain that Kim Byeong-hwa was behind it. When a rich man's son and a communist are so close, it isn't merely a friendship between old schoolmates. The Kyoto Police Division's investigation, conducted at the request of the Keijo police, showed that although Deok-gi had not acted in a particularly suspicious manner, the bookcase in his boardinghouse was noticeably ridden with books on Marx and Lenin. Furthermore, Deok-gi had given Byeong-hwa a thousand won to help him open a business- this after the two young men had been frequenting Bacchus throughout the winter, a bar whose proprietress was suspected of communist inclinations. Based on these facts, it looked like Jo Deok-gi could be what they called a sympathizer.... (Yeom 2001).

Jo Deok-gi's support for Kim Byeong-hwa can be interpreted as support for communist ideology, particularly given the findings of the police. According to one officer, many books on communism were found when Jo Deok-gi's dormitory was checked by the police. Jo Deok-gi's position can be seen as conveying the message that Koreans could escape the shackles of colonialism through communism. Extrapolating from this, it can be said that the approaches used by Jo Deok-gi are not only able to resolve problems within the family, but also in contemporary social issues. Although, communism is still portrayed as not having a bright future, it can be seen as one of the ways to escape the suppression of colonialism.

As such, it can be seen that the character Jo
Deok-gi in this novel offers a solution for the problems between Jo Ui-gwan and Jo Sang-hun. This character can be compared with Minke in the Tetralogi Buru (Buru Quartet), who likewise seeks to end colonialism in his homeland. Similarities can be found in the backgrounds of Jo Deok-gi and Minke. Both characters were educated by the colonial powers, and are skilled in the language of power and familiar with the clothing of the colonial rulers. However, there are differences between them. While Jo Deok-gi found a position between traditional culture and modernity, Minke openly rejected the values of traditional culture.

Just as Jo Deok-gi was interested in modern women, Minke did not desire to marry a purely Javanese woman who remained closely bound by traditional culture. "I do not want to marry a Javanese woman who depends on Javanese culture, as she would think that European ideals are the same and try to change my mind about the conditions we face" (Toer 2011). In this, it can be seen that Jo Deok-gi and Minke both had modern ways of thinking, which they obtained through the education made available by those in power.

On the other hand, Minke differs from Jo Deok-gi in his views of traditional culture. Unlike Jo Deok-gi, who respects traditional Korean culture, he has disdain for and actively rejects traditional Javanese culture. The Javanese distinction of people of high social status and people with low social status runs against Minke's views. Minke, who does not view Javanese culture as superior, believes that maintaining tradition without rational consideration will only hamper Indonesia's development, leading to it being "trod on like shoes" (Toer 2012). Pramoedya's views of Javanese culture are reflected in an interview with Andre Vltchek and Rosie Indira, as described below.

“... This is Javaism. It is a question of always following the orders of superiors.

Let us take another example. In the sixteenth century, those who sailed from the Netherlands to plunder, gave the village chiefs gold and silver to prevent resistance. The village residents didn't dare refuse, owing to their deep respect for greater power. This is Javaism! The entire land has been robbed, and the foreign colonials and local elites have profited" (Vltchek and Indira 2011).

From this passage, we can see Pramoedya's criticism of the colonial situation in which Javanese aristocrats followed the colonial powers in exploiting the land for their own interests, while ignoring the suffering and subjugation of those they viewed as below 
their station. As such, a Javanese lifestyle could not be considered an appropriate basis for the nation. Minke thus creates an organization for all indigenous peoples of Indonesia, not only the Javanese. He does not use Javanese as the official language of his organization, but chooses Malay as the language of integration and unity. Ultimately he establishes the Syarikat Priyayi (Union of Nobles), to unite the peoples of Indonesia during the colonial era.

As such, through Minke, Pramoedya showed that active independence movements were necessary to end colonialism. Meanwhile, Yeom Sang-seop showed a means of resolving the problems of colonial Korea through the character Jo Deok-gi. In the works of Yeom Sang-seop and Pramoedya, colonial Korea and Indonesia respectively are shown as hybrid spaces where there is a contestation of modernity and traditional culture. Through their depictions of these two novels' characters, the authors propose their own solutions for removing the shackles of colonialism.

It is interesting to note that similar contestations between traditional and modern culture emerge in the novels by Yeom Sang-seop and Pramoedya. However, there are differences between these novels. As mentioned above, the conflict in Yeom Sang-seop's Samdae (Three Generations) is presented primarily as occurring within the Jo family (grandfather, father, and grandson) and with those around them. The family conflict revolves primarily around the inheritance; the sole external conflict is the opposition to the Japanese and occupied Korea, including the anti-colonial movement. Meanwhile, the conflict in Pramoedya's tetralogy is primarily a contestation between Javanese culture and the Indonesian nation. The main character, Minke, views Javanese culture as being inappropriate for the Indonesian nation, and thus comes into opposition with the proponents of traditional culture. As such, the conflicts in these novels are different; the Korean people are a single nation, with little conflict among them. Conversely, the diversity of ethnic groups and their cultures in Indonesia has given rise to conflict and contestation.

\section{CONCLUSION}

This article sought to compare novels by famous authors from Korea and Indonesia, namely Yeom Sang-seop and Pramoedya Ananta Toer, both set in the colonial era. The contestation between traditional and modern culture in Korea is depicted in detail in Yeom Sangseop's novel Samdae (Three Generations). In this novel, the traditionalist character prioritizes rituals and honor, while in Pramoedya's tetralogy a similar character focuses solely on honor. In Yeom Sang-seop's Samdae (Three Generations), the modernist character finds himself trapped by materialism, which is not the fate of the modernist character in Pramoedya's Tetralogi Buru (Buru Quartet). Rather, in Pramoedya's novel, modernist characters are able to avoid the temptations of materialism, instead using their wealth to alleviate the suffering of others.

Through his works, Yeom Sang-seop sought a means to free the Korean people from colonialism through the character Jo Deok-gi, who showed little interest in traditional culture while avoiding the pitfalls of modern culture. At the same time however, he seemingly supported communism, something that is seen as a means for transitioning to modernity. Meanwhile, in Pramoedya's tetralogy, Minke occupies a position in colonial society similar to that of Jo Deok-gi. Minke shows that it is possible for Indonesians to free themselves from the shackles of colonialism by minimizing the practice of Javanese culture and establishing national organizations. Minke believes that, if the Indonesian people continue to emphasize Javanese culture and identity, progress will forever remain beyond their grasp.

After comparing the works of these two authors, it is interesting note that Yeom Sang-seop and Pramoedya presented similar themes in their novels. However, despite these similarities, some distinguishing characteristics have been noted. In Yeom Sang-seop's work, for example, alcohol consumption and womanizing are depicted frankly within a colonial context, something not common in Indonesian literature.

The article has compared contestations between traditional and modern culture in the novels by Yeom Sang-seop and Pramoedya Ananta Toer. Yet, there remains further scope to research other similarities between the two authors either in the same novels, or in other novels with a colonial period background for example, aspects of mimicry or imitating the colonizers, resistance or national awareness. Thus, there are further interesting topics to research in the field of Korean and Indonesian comparative literary studies.

\section{ENDNOTES}

1) The translations are mine unless they were cited.

2) The translations are mine unless they were cited.

\section{REFERENCES}

Bhabha, H. (1994). Location of Culture. London: Routledge. East, P. (2018). Tradition and Modernity in Liang Shuming's 
Eastern and Western Cultures and Their Philosophies. Philosophy East \& West, 68(2), 460-476.

Friedman, S. S. (2006). Periodizing Modernism: Postcolonial Modernities and the Space/Time Borders of Modernist Studies. Modernism/Modernity, 13(3), 425-443. https://doi.org/10.1353/mod.2006.0059

Koh, Y. H. (1993). Pramoedya-ui Soseol Ingan-ui Daejie Natanan Jeohang-ui Imiji. Dongnama Yeongu, 3(0), $1-20$.

Koh, Y. H. (2011). Pramoedya Menggugat: Melacak Jejak Indonesia. Jakarta: Gramedia Pustaka Utama

Kim, H. G. (2009). Yeom Sang-seop Soseol Dasi IlgiChurisoseoljeok Seongyeokeul Jungsimeuro. Hangukhaksuljeongbo.

Kim, J. Y. (2013). Segyemunhakeuroseo-ui Yeom Sangseop Munhak. Gukje-eo Munhakhoe Haksuldaehwe Jaryojib, 41-50.

Latifah, E. (2012). Hangukgwa Indonesia Jeonhu Soseol Bigyo Yeongu: Hwang Sun-weongwa Nugroho Notosusanto-ui Jakphumeul Jungsimeuro. PhD dissertation, Kyunghee University.

Loomba, A. (1998). Colonialism/Postcolonialism. London: New Routledge.
Munhaksasang Yeonguhoe (2008). Yeom Sang-seop Munhak-ui Jaeinsik. Seoul: Gipheunsaem.

Park, S \& Gatrall, J. J. A (translator). (2010). On the Eve of the Uprising and other stories from colonial Korea. New York: Cornell University East Asia Program.

Seth, M. J. (2011). A Concise History of Korea from Antiquity to the Present. Lanham: Rowman \& Littlefield Publishers.

Toer, P. A. (2001). Bumi Manusia. Jakarta: Lentera Dipantara.

Toer, P. A. (2011). Anak Semua Bangsa. Jakarta: Lentera Dipantara.

Toer, P. A. (2012). Jejak Langkah. Jakarta: Lentera Dipantara. Vltchek, A. \& Indira, R. (2006). Exile: Pramoedya Ananta Toer in Conversation with Andre Vltchek and Rossie Indira. Haymarket Books.

Vltchek, A. \& Indira, R. (2011). Jakgaeui Mangmyeong: Indonesia-ui Daemunho Pramoedya Ananta Toer wa-ui Daehwa. Seoul: Humanist.

Yeom, S. S. (1987). Yeom Sang-seop Jeonjib 4. Seoul: Mineumsa.

Yeom, S. S. (2005). Three Generations. Translated by Yu Young-nan. New York: Archipelago Books. 